\title{
IMPACTS OF EARNINGS MANAGEMENT ON CORPORATE FAILURE: A CASE STUDY OF WIRECARD
}

\author{
Md. Azim \\ MPhil Fellow \\ Department of Accounting \& Information Systems \\ University of Dhaka, Dhaka, Bangladesh \\ E-mail: azimbikrom@gmail.com \\ Dr. Md. Jamil Sharif \\ Associate Professor \\ Department of Accounting \& Information Systems \\ University of Dhaka, Dhaka, Bangladesh \\ E-mail: jamilais9003@du.ac.bd
}

Received: October 01, $2021 \quad$ Accepted: October 26, $2021 \quad$ Online Published: November 01, 2021

DOI: 10.46281/ijafr.v8i1.1411

URL: https://doi.org/10.46281/ijafr.v8i1.1411

\begin{abstract}
The purpose of this study is to find out whether earnings management has impacts on bankruptcy risk based on the data of Wirecard Company. The M-score of Beneish's (1999) model has been used to detect the probability of earnings management. On the other hand, the Z"-Score of Altman's (1968) model has been applied to detect Corporate Failure. Both the models are widely used models in their respective fields. The data from 2002 to 2019 were collected from the annual reports of the Wirecard Company. The result of $M$-Score indicates that earnings management has a significant impact on the corporate failure (Z-Score) of the company. This finding specifies that a financially distressed firm adopts earnings manipulations. The finding also implies that earnings manipulations harm the financial health of a firm. According to the findings, it can be suggested that to know the financial aspects of a company, both the (Beneish M-model and Altman Z-score model) models could be used concurrently. Beneish M-model is for detecting earnings management and the Altman Z-score model is for determining corporate failure. The novelty of the study is that no study was done on Wirecard Company focusing on the association between earnings management \& bankruptcy risk.
\end{abstract}

Keywords: Earnings Management, Corporate Failure, Beneish Model, Altman Model.

JEL Classification Codes: G01, G32, G33, M41.

\section{INTRODUCTION}

Before investors' investment decisions or sanctioning loans/credits by bankers/suppliers, it is necessary to know whether a company is financially healthy or prone to bankruptcy risk. Early detection of potential bankruptcy is essential to protect the stakeholders from social costs and economic losses (Hassanpour \& Ardakani, 2017). But assessing the bankruptcy risk might be difficult if there is a practice of earnings management because it reduces the information quality (Agustia et al., 2020). Since bankruptcy or corporate failure causes numerous adverse effects to the stakeholders, the managers feel 
pressure due to possible financial distress. As a result, the managers may adopt techniques to falsify the financial performance by doing earnings management to increase the income (Campa \& CamachoMiñano, 2014; Burgstahler \& Eames, 2006). To decrease the possibility of financial crises and to assist investors in avoiding huge losses, it is essential to use the tool of forecasting earnings management (Ranjbar \& Amanollahi, 2018).

Huynh (2020) defines that earnings management are the activities of higher-level executives in manipulating the earnings reported in the financial statement for different purposes. Altman et al. (2019) states that if the liabilities are higher than the asset's fair value, it can be considered as financial insolvency. After the declaration by the court, the company will be a bankrupt firm.

There were two kinds of literature on the issue of impacts of earnings management on corporate bankruptcy. Some kinds of literature show that earnings management has an impact on performance/bankruptcy risk. The study of Abbas (2018) finds that earnings management done with the income-decreasing form has a very robust effect on the increase of firm value. The study on European banks by Alhadab and Al-Own (2017) shows that the firm which does earnings management undergo inferior performance. The study of Campa and Camacho-Minano (2013) indicates that there is increasing earnings management among bankrupt companies. These practices start at least four years before the commencement of the legal process. Earnings management is done by manipulating production costs and sales. Another study by the same authors (Campa \& Camacho-Miñano, 2014) finds that insolvent firms do high earnings management compared to their healthy sets. It also finds that based on the industry, there is a change in the tools of earnings management. Smith et al. (2001) also find that financially deteriorating firms do earnings management more than healthy ones to increase income. Therefore, it can be said that earnings management has an impact on performance/bankruptcy risk.

Conversely, other works of literature show that earnings management has no impact on performance/bankruptcy risk. The study on non-financial firms by Agustia et al. (2020) shows that there is no association between earnings management $\&$ bankruptcy risk.

Since there were contrary findings on the impact of earnings management on bankruptcy risk, this study contributes to this gap. This study has originality because no study was done on Wirecard Company focusing on the association between earnings management \& bankruptcy risk yet.

The research question of this study is to test whether there is any relationship between earnings management and bankruptcy risk, or whether earnings management has an impact on bankruptcy risk. The significance of this study is that although the renowned audit firm Ernst \& Young (EY) audited the financial statements of Wirecard, it failed to identify the fraud. Ultimately both the firms (Ernst \& Young and Wirecard) faced criticism for their misconduct or unconsciousness. To avoid such failure of detection, the models for detecting earnings management and corporate failures should be used concurrently by the stakeholders especially auditors, watchdog institutions, financial analysis, etc. The authors of this study also agree with Tebogo (2011) that the model of detecting earnings management should be used before using the model for detecting corporate failure. Because the failure detection model will not work very well when the financial information is manipulated.

In this study, the M-score of Beneish's (1999) model will be used to detect the probability of earnings management. On the other hand, the Z"-Score of Altman's (1968) model will be applied to detect Corporate Failure. Both the models are widely used models in their respective fields.

The remaining of this study is structured as follows. The second section shows the literature review. The third section indicates the methodology followed in this study. The fourth section illustrates the results and discussion. The fifth section includes the conclusion.

\section{LITERATURE REVIEW}

If we focus on the ways of doing earnings management, then we find that earnings management is done in two ways: (i) using accruals to increase the profit, (ii) doing real activities to reduce avoidable expenditure such as cost for advertising, research and development, etc. (Ranjbar \& Amanollahi, 2018). Accrual management comprises advancing revenue recognition and postponing expense recognition. Accounting principles are utilized for doing accrual-based earnings management. Real earnings 
management includes reducing discretionary expenses. Nowadays business activities are changed for doing real earnings management (Sial et al., 2018; Tabassum et al., 2015).

According to Strakova (2021), the techniques of real earnings management are: shrink the ship; throw out a problem child; flushing investing portfolio; big bet on the future; postponing advertising or R\&D expenditures; accelerating advertising or R\&D expenditures; asset exchange technique; sale/leaseback; delaying sales, etc. The techniques of accrual-based earnings management are: Recording sales before they are realizable; Overstating inventory by recording fictitious inventory; Recording fictitious sales; Understatement of provisions for bad debts; Overstatement of restructuring charges and assets write-offs; Overly aggressive recognition of provisions or reserves; Backdating sales invoices; Early retirement of debt; Cookie Jar Reserve (Amortization of inventories, Warranty expense, Return of goods); Big bath; Changing in accounting standard, etc.

Now the question is why firms engage in managing its earning. From the literature, it is found that the main purpose of earnings management is for income smoothing (Alhadab \& Al-Own, 2017). Market reaction acts as a significant factor for earnings management because reported low earnings affect the share price adversely. Besides, fluctuated earnings raise questions against the firms.

Another reason for earnings management is to obtain a better amount of bonus by showing good performance. Fear of investigation by regulatory bodies may also act as a reason for earnings management. Hiding financial distress is another reason for doing earnings management. By hiding financial distress a company tries to protect its reputation (Agrawal \& Chatterjee, 2015). Another study on Chinese firms by Aharony et al. (2000) finds that companies do earnings management before Initial Public Offerings (IPO) to make the share attractive to the potential investors. Firms also adopt earnings management to evade debt contract violations (Filip \& Raffournier, 2014). The study of Strakova (2021) summarizes all the motives of doing earnings management. These are: evading technical default on debts agreements; favorable agreements from employees, lenders, customers, and suppliers; hiding of bad performance; extracting external finance; evading tax; ensuring expected compensation by managers; showing better financial performance than past; avoiding negative earnings; beating the expectations of the analyst's; ensuring better securities price, etc.

Up to the above discussion the study has focused on the issues of earnings management. Since this study is on the influence of earnings management on corporate failure, the next part of the literature describes the issues of corporate failure.

If the liabilities are higher than the asset's fair value, then it can be considered as financial insolvency. After the declaration by the court, the company will be a bankrupt firm (Altman et al., 2019).

There is a relationship between earnings management and corporate failure. The study by Hassanpour and Ardakani (2017) shows that there is a relationship between earnings management and pre-insolvency financial distress. The study by Agrawal and Chatterjee (2015) on financially distressed Indian companies shows that low distressed companies are involved in greater earnings management. On the other hand, the study by Charitou et al. (2007) on US distressed firms indicates that there is higher earnings management in the healthy firms compared to the distressed firms. The same view is provided by Smith et al. (2001). The firm which is distressed but not failing immediately engages in more earnings management to increase the earnings. On the other hand, the firm which is distressed and failing in a short time does not adopt frequent income-increasing practices. The study by Filip and Raffournier (2014) implies that there is a noteworthy reduction in income smoothing in the macroeconomic crisis time. The finding by Li and Zhou (2006) indicates that Initial Public Offering companies connected with high earnings management are more possibly to delist due to performance failure.

Sial et al. (2018) finds that earnings management has a negative impact on firm performance. The same view is provided by Tabassum et al. (2015). Companies involved in real earnings manipulation practices through sales management to increase earnings have inferior financial performance in the future. Earnings management decreases corporate value and reputation (Roychowdhury, 2006).

The study by Kumari and Pattanayak (2017) on Indian banks indicates that market-based firm performance is considerably associated with earnings management. The study by Ranjbar and 
Amanollahi (2018) finds that companies with financial distress are more engaged in earnings management. Thus, it can be said that there is a relationship between earnings management and financial distress. But the findings by Franceschetti (2017) specifies that financial crisis does not influence earnings management. However, there is a connection between a troubled firm and a deceitful company. Deloitte (2008) indicates that there is a great possibility of engaging earnings management when a company is at the edge of bankruptcy. The same view is provided by Serrano-Cinca et al. (2019) that a firm that is experiencing financial distress is engaged in accounting fraud, profits smoothing, earnings management, and creative accounting practices.

The occurrence of earnings management is one of the preliminary reasons that lead to a dwindling of the financial health of companies and finally results in their failure. The same opinion is provided by Kwarbai et al. (2019). It opines that although earnings management is allowed within the accounting standards, aggressive use may produce implications on its going concern and eventual survival.

MacCarthy (2017) opines that to know the financial aspects of a firm in a better way, both the (Beneish M-model and Altman Z-score model) models should be used concurrently. Beneish M-model is for detecting earnings management or financial fraud and the Altman Z-score model is for determining corporate failure.

Considering the above discussion, the research hypothesis can be stated as follows:

\section{$H_{1}$ : Earnings management has a significant impact on the corporate failure of a company.}

Therefore, this study will utilize two models, Beneish M-score and Altman Z-score models concurrently considering that a financially distressed firm does not provide a fair and true financial report. Before applying the model of predicting corporate failure, it is worthy to use the earnings management detection model.

\section{Sample Selection and Data Collection}

\section{METHODOLOGY}

This is a case study on Wirecard focusing on the impacts of earnings management on corporate failure. For that purpose, data were collected from the annual reports of the Wirecard Company. The annual reports from 2002 to 2019 were found from online sources. The related data for detecting earnings management and corporate failure have been taken for this study. The details of the variables can be found in the following description.

\section{Tools for Detecting Earnings Management}

The most widely used model for detecting earnings management is Beneish's (1999) model. This model indicates M-score to indicate the probability of earnings management. This model uses eight variables which are:

DSRI= Days Sales in Receivables Index

GMI $=$ Gross Margin Index

AQI = Asset Quality Index

SGI $=$ Sales Growth Index

DEPI= Depreciation Index

SGAI $=$ Sales General and Administrative Expenses Index

ACC $=$ Accruals

LEVI= Leverage Index

The estimated model (Beneish et al., 2013) for detecting the probability of manipulation is: 
M-Score $=-4.84+0.920(\mathrm{DSRI})+0.528(\mathrm{GMI})+0.404(\mathrm{AQI})+0.892(\mathrm{SGI})+0.115(\mathrm{DEPI})-$ $0.172(\mathrm{SGAI})+4.679(\mathrm{ACC})-0.327(\mathrm{LEVI})$

Days Sales in Receivables Index (DSRI) indicates the inconsistent increase in Receivable relative to sales. Such an asymmetrical increase in Receivables implies the probability of earnings management.

$$
\text { DSRI }=\left(\text { Receivables }_{\mathrm{t}} \div \text { Sales }_{\mathrm{t}}\right) \div\left(\text { Receivables }_{\mathrm{t}-1} \div \text { Sales }_{\mathrm{t}-1}\right)
$$

Gross Margin Index (GMI) is the gross margin ratio. Worsening gross margins indicates the symptoms of earnings manipulations.

$$
\text { GMI }=\left\{\left(\text { Sales }_{t-1}-\text { Cost of Goods Sold } t-1\right) \div\left(\text { Sales }_{t-1}\right)\right\} \div\left\{\left(\text { Sales }_{t}-\text { Cost }_{\text {of Goods Sold }}\right) \div\left(\text { Sales }_{t}\right)\right\}
$$

Asset Quality Index (AQI) is the ratio of non-current assets excluding the property plant and equipment to total assets. This ratio expresses the falsifications in other assets that are the outcome of excessive expenditure capitalization.

$\mathrm{AQI}=[1-(\mathrm{PPEt}+\mathrm{CAt}) / \mathrm{TAt}] /[1-(\mathrm{PPEt}-1+\mathrm{CAt}-1) / \mathrm{TAt}-1]$, Where PPE is the Property Plant and Equipment, $\mathrm{CA}$ is the Current Assets, and TA is the Total Assets.

Sales Growth (SG) is not an indication of actual manipulation. Nevertheless, persistent growth symbolizes that the manager may adopt techniques to manage earnings and sales because there might be pressure on the manager to attain the target growth.

$$
\mathrm{SGI}=\text { Sales }_{\mathrm{t}} \div \text { Sales }_{\mathrm{t}-1}
$$

If the value of the Depreciation Index (DEPI) ratio is higher than 1, then it implies that the depreciation rate has been slowed by changing the depreciation rate/method for the assets to increase the earnings.

DEPI $=\left\{\right.$ Depreciation $\operatorname{Exp}_{\mathrm{t}} \div\left(\right.$ Depreciation $\left.\left.\operatorname{Exp}_{\mathrm{t}}+\mathrm{PPE}_{\mathrm{t}}\right)\right\} \div\left\{\right.$ Depreciation $\operatorname{Exp}_{\mathrm{t}-1} \div\left(\right.$ Depreciation Exp $_{\mathrm{t}-}$ $\left.\left.{ }_{1}+\mathrm{PPE}_{\mathrm{t}-1}\right)\right\}$, Where PPE is the Property Plant and Equipment

If the score of the Sales General and Administrative Expenses Index (SGAI) is higher than 1, then it indicates that there is manipulation because the disproportionate increase in sales implies a negative indicator about the prospects of the firm.

$$
\mathrm{SGAI}=\left(\mathrm{SGA}_{\mathrm{t}} \div \text { Sales }_{\mathrm{t}}\right) \div\left(\mathrm{SGA}_{\mathrm{t}-1} \div \text { Sales }_{\mathrm{t}-1}\right)
$$

The Accruals (ACC) represent the manipulation if the accounting profits are not supported by cash profits. Accruals are the tools to modify the timing of reported earnings.

$$
\text { Accruals }=\left(\text { Income before extraordinary items }_{t}-\text { Cash from operations } t_{t}\right) \div \text { Total Assets } s_{t}
$$

If the value of the Leverage Index (LEVI) is higher than 1, then it indicates that there is an increase in leverage. Since increasing leverage tightens debt constraints that is why it predisposes companies to manipulate earnings.

$$
\text { LEVI }=\left(\text { Total Debt }_{\mathrm{t}} \div \text { Total Assets } \mathrm{t}\right) \div\left(\text { Total Debt }_{\mathrm{t}-1} \div \text { Total Assets }_{\mathrm{t}-1}\right)
$$

According to Beneish et al. (2013), if the M-Score is higher than -1.78, then it shows the possibility of earnings management. 
The collected data for the above variables were compiled in an excel sheet. After applying the model of Beneish (1999), the M-Scores were calculated. Then the calculation was presented in a table showing the M-Scores.

\section{Tools for Detecting Corporate Failure}

Altman's (1968) model is a widely used model for detecting corporate failure. To detect the corporate failure, the Z"-Score model (Altman, 1993) for a non-manufacturing firm is as follows:

Where,

$$
Z^{\prime \prime}=6.56(X 1)+3.26(X 2)+6.72(X 3)+1.05(X 4)
$$

$\mathrm{Z}^{\prime \prime}=$ Overall Score

$\mathrm{X} 1=($ Current assets - Current liabilities $) /$ Total Assets

$\mathrm{X} 2=$ Retained Earnings/Total Assets

X3= Earnings Before Interest and Taxes /Total Assets

X4= Book Value of Equity/Total Liabilities.

For the above formula, if the Z"-Scores is less than 1.10, then it specifies an insolvent firm. If the Z"Score is above 2.60, then it means a non-bankrupt firm. The $Z$ "-Score of 1.10 to 2.60 indicates a grey zone (Altman, 1993).

Collected data regarding the above variables have been compiled in an excel file. After calculating the ratios, the Z"-Scores are calculated based on the model.

\section{Model for the Study}

The main focus of this study is to find out the impact of earnings management on corporate failure. To show the impacts of earnings management on corporate failure, the following model is used:

$$
Z^{\prime \prime}-\text { Score }_{t}=\beta_{0}+\beta_{1} \text { MScore }_{t}+\beta_{2} \text { Age }_{t}+\beta_{3} \text { Size }_{t}+\varepsilon
$$

Table 1. Explanation of the variables for the model for this study

\begin{tabular}{|l|l|l|}
\hline Dependent Variable & Z"'-Score & Z-Score is taken by applying the Altman (1968) model \\
\hline Independent Variable & M-Score & $\begin{array}{l}\text { M-Score is taken by applying the Beneish et al. (2013) } \\
\text { model }\end{array}$ \\
\hline Control Variables & Age & $\begin{array}{l}\text { Age is the control variable that is measured by the } \\
\text { number of years after the founding of the company. }\end{array}$ \\
\cline { 2 - 3 } & Size & $\begin{array}{l}\text { Size is the control variable that is measured by the } \\
\text { natural logarithm of total assets. }\end{array}$ \\
\hline
\end{tabular}

IBM SPSS Statistics 22 software is used for the above regression model. The output is presented in the tables.

\section{Descriptive Statistics of the Variables of M-Score}

\section{RESULTS AND DISCUSSION}

The descriptive statistics of the variables of M-Score (Beneish et al., 2013) is shown in Table 2.

Table 2. Descriptive Statistics of the Variables of M-Score

\begin{tabular}{|l|c|c|c|c|c|}
\hline & $\mathrm{N}$ & Minimum & Maximum & Mean & Std. Deviation \\
\hline Days Sales in Receivables Index (DSRI) & 18 & .40 & 8.20 & 1.395 & 1.72354 \\
\hline Gross Margin Index (GMI) & 18 & .65 & 1.32 & .9962 & .14457 \\
\hline
\end{tabular}




\begin{tabular}{|l|c|c|c|c|c|}
\hline Asset Quality Index (AQI) & 18 & .35 & 4.87 & 1.145 & .94868 \\
\hline Sales Growth Index (SGI) & 18 & 1.04 & 7.19 & 1.667 & 1.38968 \\
\hline Depreciation Index (DEPI) & 18 & .00 & 1.33 & .9431 & .29464 \\
\hline Sales Gen. \& Admin Exp. Index (SGAI) & 18 & .55 & 1.12 & .8964 & .16416 \\
\hline Accruals (ACC) & 18 & -.71 & .17 & -.0447 & .17681 \\
\hline Leverage Index (LEVI) & 18 & .34 & 3.05 & 1.147 & .55894 \\
\hline
\end{tabular}

The maximum value (8.20) of the Days Sales in Receivables Index (DSRI) indicates the inconsistent increase in receivables relative to sales. Such an asymmetrical increase in receivables compared to the mean value (1.39) implies the probability of earnings management. The mean value (0.9962) of the Gross Margin Index (GMI) represents the worsening gross margins that indicate the symptoms of earnings manipulations. The maximum value (4.87) of the Asset Quality Index (AQI) shows that there is a practice of falsifications in other assets compared to total assets that are the outcome of excessive expenditure capitalization. Persistent Sales Growth (SG) symbolizes that the manager may adopt techniques to manage earnings and sales because there might be pressure on the manager to attain the target growth. The maximum value (7.19) of the Sales Growth Index (SGI) shows that management has done manipulation to a great level in one of the years. The maximum value (1.33) of the Depreciation Index (DEPI) shows that the management adopted manipulations in one of the years, because if the value of the Depreciation Index (DEPI) ratio is higher than 1, then it implies that the depreciation rate has been slowed by changing the depreciation rate/method for the assets to increase the earnings. The maximum value (1.12) of the Sales, General, and Administrative Expenses Index (SGAI) demonstrates that the management embraced manipulations in one of the years. If the score of the Sales General and Administrative Expenses Index (SGAI) is higher than 1, then it indicates that there is manipulation because a disproportionate increase in sales implies a negative indicator about the prospects of the firm. The negative mean value (-.0447) of the Accruals (ACC) indicates that there is an inconsistency between accounting profits and cash profits. There might be manipulation if the accounting profits are not supported by cash profits. We know that accruals are the tools to modify the timing of reported earnings. The mean value (1.147) of the Leverage Index (LEVI) implies the possibility of manipulations. If the value of the Leverage Index is higher than 1, then it indicates that there is an increase in leverage. Since increasing leverage tightens debt constraints that is why it predisposes companies to manipulate earnings.

\section{Descriptive Statistics of the Variables of Z-Score}

The descriptive statistics of the variables of Z"-Score (Altman, 1993) is presented in Table 3.

Table 3. Descriptive Statistics of the Variables of Z"-Score

\begin{tabular}{|l|c|c|c|c|c|}
\hline & $\mathrm{N}$ & Minimum & Maximum & Mean & Std. Deviation \\
\hline $\begin{array}{l}\text { X1= (Current assets - Current liabilities)/Total } \\
\text { Assets }\end{array}$ & 18 & -.35 & .32 & .1499 & .14079 \\
\hline X2= Retained Earnings/Total Assets & 18 & -.15 & .32 & .1699 & .13503 \\
\hline $\begin{array}{l}\text { X3= Earnings Before Interest and Taxes /Total } \\
\text { Assets }\end{array}$ & 18 & -1.76 & .12 & -.0253 & .43377 \\
\hline X4= Book Value of Equity/Total Liabilities. & 18 & .00 & 2.38 & .9654 & .58379 \\
\hline
\end{tabular}

The minimum value of the $\mathrm{X} 1$ variable is negative $(-0.35)$ which indicates that there was a liquidity crisis in any one of the years. When a company undergoes consistent losses from the operation, then there will be dwindling current assets compared to total assets. In the early stage of a firm, there is a possibility of low retained earnings which may influence financial distress due to low internal funds. 
The minimum value $(-0.15)$ of $\mathrm{X} 2$ indicates the situation of negative retained earnings. The mean value of $\mathrm{X} 3$ is in a negative (-0.0253) position which implies that there is adverse profitability. The adverse profitability leads to corporate failure. The minimum value $(0.00)$ of X4 is showing that there was zero equity which creates a critical situation for quick insolvency.

\section{Correlation Analysis}

The Pearson correlation table shows that the value of correlation between Z-Score and M-Score is 0.079 , but this correlation is not significant due to a higher $p$-value $(\alpha=0.755)$.

Table 4. Correlations between the variables

\begin{tabular}{|c|c|c|c|c|c|}
\hline & & Zscore & Mscore & Age & Size \\
\hline \multirow[t]{2}{*}{ Zscore } & Pearson Correlation & 1 & -.079 & .418 & $.628^{* *}$ \\
\hline & Sig. (2-tailed) & & .755 & .084 & .005 \\
\hline \multirow[t]{2}{*}{ Mscore } & Pearson Correlation & -.079 & 1 & $-.559^{*}$ & $-.597^{* *}$ \\
\hline & Sig. (2-tailed) & .755 & & .016 & .009 \\
\hline \multirow[t]{2}{*}{ Age } & Pearson Correlation & .418 & $-.559^{*}$ & 1 & $.936^{* * *}$ \\
\hline & Sig. (2-tailed) & .084 & .016 & & .000 \\
\hline \multirow[t]{2}{*}{ Size } & Pearson Correlation & $.628^{* *}$ & $-.597^{* *}$ & $.936^{* *}$ & 1 \\
\hline & Sig. (2-tailed) & .005 & .009 & .000 & \\
\hline
\end{tabular}

\section{M-Score Calculation}

The M-Score was calculated using the model of Beneish et al. (2013). This M-Score will represent the symptoms of earnings management of the firm. The results of the M-Score calculation is presented in Table 5.

Table 5. M-Score as the representation of Earnings Management

\begin{tabular}{|c|c|c|c|c|c|c|c|c|c|}
\hline Year & DSRI & GMI & AQI & SGI & DEPI & SGAI & ACC & LEVI & M-Score \\
\hline $\mathbf{2 0 1 9}$ & 1.16 & 0.99 & 0.84 & 1.28 & 0.82 & 0.98 & 0.03 & 1.00 & -2.05 \\
\hline 2018 & 1.08 & 1.02 & 0.83 & 1.35 & 0.95 & 0.84 & -0.03 & 1.05 & -2.27 \\
\hline 2017 & 0.83 & 1.03 & 0.99 & 1.45 & 1.02 & 1.05 & -0.03 & 1.11 & -2.42 \\
\hline 2016 & 0.99 & 0.94 & 0.90 & 1.33 & 0.97 & 1.07 & 0.00 & 1.02 & -2.26 \\
\hline 2015 & 0.98 & 0.95 & 1.07 & 1.28 & 0.90 & 1.03 & -0.04 & 1.22 & -2.54 \\
\hline 2014 & 1.02 & 0.93 & 0.99 & 1.25 & 1.08 & 1.00 & 0.00 & 0.80 & -2.22 \\
\hline 2013 & 1.06 & 1.04 & 1.01 & 1.22 & 1.16 & 1.12 & -0.02 & 1.11 & -2.31 \\
\hline 2012 & 0.97 & 1.00 & 0.96 & 1.21 & 0.76 & 0.96 & 0.00 & 1.00 & -2.36 \\
\hline 2011 & 1.28 & 1.05 & 0.98 & 1.20 & 0.95 & 0.93 & 0.04 & 1.10 & -1.85 \\
\hline 2010 & 1.24 & 1.02 & 1.25 & 1.19 & 1.06 & 0.92 & 0.17 & 0.86 & $\mathbf{- 1 . 1 4}$ \\
\hline 2009 & 1.22 & 0.98 & 0.88 & 1.16 & 1.08 & 1.00 & -0.02 & 1.08 & -2.29 \\
\hline 2008 & 0.51 & 1.04 & 0.97 & 1.47 & 1.33 & 0.89 & 0.02 & 0.86 & -2.32 \\
\hline 2007 & 0.81 & 1.07 & 0.92 & 1.64 & 0.84 & 0.84 & -0.16 & 1.23 & -2.90 \\
\hline 2006 & 1.45 & 0.92 & 0.87 & 1.67 & 1.30 & 0.96 & 0.00 & 1.61 & $\mathbf{- 1 . 7 3}$ \\
\hline 2005 & 0.40 & 1.22 & 1.22 & $\mathbf{7 . 1 9}$ & 1.18 & 0.60 & -0.03 & 0.63 & 2.78 \\
\hline 2004 & 1.40 & 1.32 & 0.72 & 1.48 & 0.93 & 0.68 & 0.02 & 1.57 & $\mathbf{- 1 . 6 5}$ \\
\hline 2003 & 8.20 & 0.77 & 4.87 & 1.59 & 0.64 & 0.55 & -0.04 & 0.34 & $\mathbf{6 . 1 7}$ \\
\hline 2002 & 0.48 & 0.65 & 0.35 & 1.04 & \#DIV/0! & 0.71 & -0.71 & $\mathbf{3 . 0 5}$ & \#DIV/0! \\
\hline
\end{tabular}


After the calculation of M-Score by using the model of Beneish et al. (2013), the findings show that there is a sign of earnings management in some of the years of the sample years. If the M-Score is higher than -1.78 , then it implies the possibility of earnings management. Based on this benchmark for identifying symptoms of earnings management, the results show that there was earnings management in the years of 2010, 2006, 2004, and 2003 because the M-Score are $-1.14,-1.73,-1.65$, and 6.17 that are higher than the benchmark $(-1.78)$.

\section{Z"- Score Calculation}

The Z"-Score was calculated using the model of Altman (1993). This Z"-Score will represent the insolvency position of the firm. The results of the Z"-Score calculation is shown in Table 6.

Table 6. Z"-Score as the representation of Corporate Failure or Bankruptcy Risk

\begin{tabular}{|c|c|c|c|c|c|}
\hline Year & X1 & X2 & X3 & X4 & Z"- Score \\
\hline $\mathbf{2 0 1 9}$ & 0.32 & 0.25 & 0.06 & 0.49 & 3.86 \\
\hline 2018 & 0.27 & 0.23 & 0.07 & 0.49 & 3.56 \\
\hline 2017 & 0.17 & 0.24 & 0.07 & 0.57 & 2.95 \\
\hline 2016 & 0.22 & 0.24 & 0.07 & 0.73 & 3.43 \\
\hline 2015 & 0.16 & 0.20 & 0.06 & 0.77 & 2.93 \\
\hline 2014 & 0.20 & 0.23 & 0.07 & 1.16 & 3.75 \\
\hline 2013 & 0.19 & 0.25 & 0.07 & 0.74 & 3.28 \\
\hline 2012 & 0.17 & 0.26 & 0.08 & 0.92 & 3.46 \\
\hline 2011 & 0.22 & 0.32 & 0.11 & 0.93 & 4.16 \\
\hline 2010 & 0.11 & 0.32 & 0.12 & 1.12 & 3.79 \\
\hline 2009 & 0.13 & 0.24 & 0.10 & 0.83 & 3.21 \\
\hline 2008 & 0.12 & 0.22 & 0.12 & 0.97 & 3.34 \\
\hline 2007 & 0.04 & 0.13 & 0.08 & 0.70 & $\mathbf{1 . 9 6}$ \\
\hline 2006 & 0.13 & 0.10 & 0.09 & 1.09 & 2.97 \\
\hline 2005 & 0.22 & 0.05 & 0.08 & 2.38 & 4.64 \\
\hline 2004 & 0.13 & $\mathbf{- 0 . 1 1}$ & 0.04 & 1.13 & $\mathbf{1 . 9 9}$ \\
\hline 2003 & 0.24 & $\mathbf{- 0 . 1 5}$ & 0.01 & 2.35 & 3.64 \\
\hline 2002 & $\mathbf{- 0 . 3 5}$ & 0.02 & $\mathbf{- 1 . 7 6}$ & $\mathbf{0 . 0 0}$ & $\mathbf{- 1 4 . 1 2}$ \\
\hline 2001 & 0.22 & 0.00 & $\mathbf{- 1 . 1 1}$ & 2.46 & $\mathbf{- 3 . 4 3}$ \\
\hline
\end{tabular}

After the calculation of the Z"-Score by using the model of Altman (1993), the findings show that there is an indication of financial distress in some of the years of the sample years. If the Z"-Score is less than 1.10, then it specifies an insolvent firm. Based on this benchmark for identifying symptoms of financial distress, the results show that there were insolvencies in the years of 2002 and 2001 because the Z"-Score are -14.12 and -3.43 respectively which are lower than the benchmark (1.10). On the other hand, if the Z"-Score is between 1.10 to 2.60, then it indicates a grey zone (prone to insolvency). Based on this benchmark, two years are in the grey zone which are 2007 and 2004 with the Z"-Score of 1.96 and 1.99 respectively. If the $Z "-S c o r e$ is above 2.60 , then it means a non-bankrupt firm.

\section{Regression Analysis}

The value of $\mathrm{R}(0.873)$ shows the correlation between independent and dependent variables. The value of Adjusted R Square (0.711) shows the proportion of variability in the dependent variable (Z-Score) that is explained by independent variables (M-Score, Age, Size). 
Table 7. Model Summary

\begin{tabular}{|l|c|c|c|c|}
\hline Model & $\mathrm{R}$ & $\mathrm{R}$ Square & Adjusted R Square & Std. Error of the Estimate \\
\hline 1 & $.873^{\mathrm{a}}$ & .762 & .711 & 2.24228 \\
\hline
\end{tabular}

a. Predictors: (Constant), M-Score, Age, Size

This Adjusted R Square indicates that $71 \%$ of the variation of the dependent variable (Z-Score) is caused by independent variables (M-Score, Age, Size) of this regression model considering the sample size.

Table 8. ANOVA ${ }^{\mathrm{a}}$

\begin{tabular}{|l|l|c|c|c|c|c|}
\hline Model & Sum of Squares & df & Mean Square & F & Sig. \\
\hline \multirow{4}{*}{1} & Regression & 225.165 & 3 & 75.055 & 14.928 & $\mathbf{. 0 0 0}^{\mathbf{b}}$ \\
\cline { 2 - 6 } & Residual & 70.389 & 14 & 5.028 & & \\
\cline { 2 - 6 } & Total & 295.555 & 17 & & & \\
\hline
\end{tabular}

The ANOVA table is showing the F Statistic. The F Statistic is a test of significance for the entire regression. At $\alpha=0.05$, this regression is statistically significant because the $p$-value is lower than 0.05 .

Table 9. Coefficients ${ }^{\mathrm{a}}$ from the Regression Output

\begin{tabular}{|c|c|c|c|c|c|c|}
\hline \multirow{2}{*}{\multicolumn{2}{|c|}{ Model }} & \multicolumn{2}{|c|}{ Unstandardized Coefficients } & \multirow{2}{*}{$\begin{array}{c}\text { Standardized } \\
\text { Coefficients }\end{array}$} & \multirow[b]{2}{*}{$\mathrm{t}$} & \multirow[b]{2}{*}{ Sig. } \\
\hline & & B & Std. Error & & & \\
\hline \multirow[t]{4}{*}{1} & (Constant) & -8.655 & 1.789 & & -4.839 & .000 \\
\hline & M-Score & .847 & .299 & .461 & 2.833 & .013 \\
\hline & Age & -1.069 & .290 & -1.368 & -3.690 & .002 \\
\hline & Size & 3.944 & .692 & 2.184 & 5.696 & .000 \\
\hline
\end{tabular}

The study hypothesizes that earnings management has a significant impact on the corporate failure of a company. From the regression, the coefficient (0.847) of M-Score from the regression output indicates that earnings management has a significant $(\mathrm{p}$-value $=0.013$ ) impact on the corporate failure (Z-Score) of the company. From the coefficients, the model can be represented as follows:

$$
\text { Z-Score }=-8.655+0.847(\mathrm{M}-\mathrm{Score})-1.069(\mathrm{Age})+3.944(\text { Size })
$$

The value of $\beta_{1}$ is 0.847 , indicating that for every 1 unit of increase of M-Score, the Z-Score will vary by about 0.847 , with other variables held constant. Thus, there is a significant impact of earnings management on corporate failure.

From these findings, we can say that a financially distressed firm may adopt earnings manipulations, or conversely, we can say that earnings manipulations harm the financial health of a firm. This finding is consistent with Ranjbar and Amanollahi (2018), Serrano-Cinca et al. (2019), Kwarbai et al. (2019), and Deloitte (2008).

According to the findings and in tune with MacCarthy (2017), it can be suggested that to know the financial aspects of a company both the (Beneish M-model and Altman Z-score model) models could 
be used concurrently. Beneish M-model is for detecting earnings management and the Altman Z-score model is for determining corporate failure.

\section{CONCLUSIONS}

The research question of this study is to test whether there is any relationship between earnings management and bankruptcy risk, Or whether earnings management has impacts on bankruptcy risk. The result indicates that earnings management has a significant impact on the corporate failure of the company. This finding is similar to Ranjbar and Amanollahi (2018), Serrano-Cinca et al. (2019), Kwarbai et al. (2019), and Deloitte (2008). From the finding, it can be concluded that the existence of earnings management could lead to a deteriorating of the financial health of companies and finally result in their failure because aggressive use of earnings management may create implications on its going concern and eventual survival. Besides, earnings management reduces corporate value and reputation.

The theoretical implications of the result of this study are that the findings support the theory of MacCarthy (2017) that to know the financial aspects of a company both the (Beneish M-model and Altman Z-score model) models could be used concurrently. Beneish M-model is for detecting earnings management and the Altman Z-score model is for determining corporate failure.

The managerial implication of this study is that although the renowned audit firm Ernst \& Young (EY) audited the financial statements of Wirecard, it has failed to identify the fraud. Ultimately both the firms (Ernst \& Young and Wirecard) faced criticism for their misconduct or unconsciousness. To avoid such failure of detection, the models for detecting earnings management and corporate failures should be used concurrently by the stakeholders especially auditors, watchdog institutions, financial analysis, etc. The authors of this study also agree with Tebogo (2011) that the model of detecting earnings management should be used before using the model for detecting corporate failure. Because the failure detection model will not work very well when the financial information is manipulated.

The limitation of this study is that the findings are based on the data of a single firm. Thus, these findings could not be generalized. But a more rigorous future study could be done focusing on this issue by using enough data from large numbers of firms.

\section{REFERENCES}

Abbas, A. (2018). Earnings Management in Banking Industry and Its Impact on the Firm Value, AKRUAL: Jurnal Akuntansi, 10(1), 69-84. http://dx.doi.org/10.26740/jaj.v10n1.p69-84

Agrawal, K., \& Chatterjee, C. (2015). Earnings Management and Financial Distress: Evidence from India. Global Business Review, 16(5), 140S-154S. http://dx.doi.org/10.1177/0972150915601928

Agustia, D., Muhammad, N. P. A., \& Permatasari, Y. (2020). Earnings management, business strategy, and bankruptcy risk: evidence from Indonesia. Heliyon, 6(2), e03317. http://dx.doi.org/10.1016/j.heliyon.2020.e03317

Aharony, J., Lee, C.W. J., \& Wong, T. J. (2000). Financial Packaging of IPO Firms in China. Journal of Accounting Research, 38(1), 103. http://dx.doi.org/10.2307/2672924

Alhadab, M.M., \& Al-Own, B. (2017). Earnings Management and Banks Performance: Evidence from Europe. International Journal of Academic Research in Accounting, Finance and Management Sciences, 7(4), 134-145. http://dx.doi.org/10.6007/IJARAFMS/v7-i4/3444

Altman, E. I. (1968). Financial ratios, discriminant analysis and the prediction of corporate bankruptcy. The Journal of Finance, 23(4), 589-609. 
Altman, E. I. (1993). Corporate Financial Distress and Bankruptcy: A Complete Guide to Predicting and Avoiding Distress and Profiting from Bankruptcy, New York: Wiley.

Altman, E. I., Hotchkiss, E., \& Wang, W. (2019). Corporate Financial Distress, Restructuring, and Bankruptcy, pp. 1-20, Hoboken, New Jersey, United States: John Wiley \& Sons, Inc. https://doi.org/10.1002/9781119541929.ch1

Beneish, M. D. (1999). The Detection of Earnings Manipulation. Financial Analysts Journal, 55(5), 24-36. http://dx.doi.org/10.2469/faj.v55.n5.2296

Beneish, M. D., Lee, C. M. C., \& Nichols, D. C. (2013). Earnings Manipulation and Expected Returns. Financial Analysts Journal, 69(2). http://dx.doi.org/10.2469/faj.v69.n2.1

Burgstahler, D., \& Eames, M. (2006). Management of Earnings and Analysts' Forecasts to Achieve Zero and Small Positive Earnings Surprises. Journal of Business Finance Accounting, 33(5-6), 633-652. http://dx.doi.org/10.1111/j.1468-5957.2006.00630.x

Campa, D., \& Camacho-Miñano, M. D. M. (2014). Earnings management among bankrupt non-listed firms: evidence from Spain. Spanish Journal of Finance and Accounting/Revista Espanola de Financiacion y Contabilidad, 43(1), 3-20. http://dx.doi.org/10.1080/02102412.2014.890820

Campa, D., \& Miñano, M. D. M. C. (2013). Opportunistic earnings manipulation among bankrupt unlisted firms-How and when they do that-[Manipulacion de resultados oportunista entre empresas en concurso no cotizadas-cómo y cuando lo hacen-] (No. 13-05). Universidad Complutense de Madrid, Facultad de Ciencias Económicas y Empresariales.

Charitou, A., Lambertides, N., \& Trigeorgis, L. (2007). Managerial discretion in distressed firms. The British Accounting Review, 39(4), 323-346. http://dx.doi.org/10.1016/j.bar.2007.08.003

Deloitte. (2008). Ten Things about Financial Statement Fraud (3rd ed.). Retrieved from https://assets.corporatecompliance.org

Filip, A., \& Raffournier, B. (2014). Financial Crisis and Earnings Management: The European Evidence. The International Journal of Accounting, 49(4), 455-478. http://dx.doi.org/10.1016/j.intacc.2014.10.004

Franceschetti, B. M. (2017). Does Financial Crisis Cause Earnings Management?. Contributions to Management Science, 119-161. http://dx.doi.org/10.1007/978-3-319-54121-1_5

Hassanpour, S., \& Ardakani, M.N. (2017). The Effect of Pre-bankruptcy Financial Distress on Earnings Management Tools. International Review of Management and Marketing, 7(3), 213-219.

Huynh, Q.L. (2020). A Triple of Corporate Governance, Social Responsibility and Earnings Management. The Journal of Asian Finance, Economics and Business, 7(3), 29-40. https://doi.org/10.13106/JAFEB.2020.VOL7.NO3.29

Kumari, P., \& Pattanayak, J. K. (2017). Linking earnings management practices and corporate governance system with the firms' financial performance. Journal of Financial Crime, 24(2), 223-241. http://dx.doi.org/10.1108/jfc-03-2016-0020 
Kwarbai, J., Nwaobia, A., \& Jayeoba, O. (2019). Earnings management and corporate survival of listed manufacturing companies in Nigeria. International Journal of Development and Sustainability, 8(2), 97-115.

Li, J., \& Zhou, J. (2006). Earnings Management and Delisting Risk of Initial Public Offerings, Simon School, University of Rochester, Research Paper Series, AAA 2008 Financial Accounting and Reporting Section (FARS). http://dx.doi.org/10.2139/ssrn.641021

MacCarthy, J. (2017). Using Altman Z-score and Beneish M-score Models to Detect Financial Fraud and Corporate Failure: A Case Study of Enron Corporation. International Journal of Finance and Accounting, 6(6), 159-166. http://dx.doi.org/10.5923/j.ijfa.20170606.01

Ranjbar, S., \& Amanollahi, G.F. (2018). The effect of financial distress on earnings management and unpredicted net earnings in companies listed on Tehran Stock Exchange. Management Science Letters, 8(9), 933-938. http://dx.doi.org/10.5267/j.msl.2018.6.015

Roychowdhury, S. (2006). Earnings management through real activities manipulation. Journal of Accounting and Economics, 42(3), 335-370. http://dx.doi.org/10.1016/j.jacceco.2006.01.002

Serrano-Cinca, C., Gutiérrez-Nieto, B., \& Bernate-Valbuena, M. (2019). The use of accounting anomalies indicators to predict business failure. European Management Journal, 37(3), 353375, http://dx.doi.org/10.1016/j.emj.2018.10.006

Sial, M. S., Chunmei, Z., Khan, T., \& Nguyen, V. K. (2018). Corporate social responsibility, firm performance and the moderating effect of earnings management in Chinese firms. Asia-Pacific Journal of Business Administration, 10(2/3), 184-199. http://dx.doi.org/10.1108/APJBA-032018-0051

Smith, M., Kestel, J.A., \& Robinson, P. (2001). Economic Recession, Corporate Distress and Income Increasing Accounting Policy Choice. Accounting Forum, 25(4), 334-352. http://dx.doi.org/10.1111/1467-6303.00070

Strakova, L. (2021). Motives and techniques of earnings management used in a global environment, SHS Web of Conferences, 92, 02060. https://doi.org/10.1051/shsconf/20219202060

Tabassum, N., Kaleem, A., \& Nazir, M. S. (2015). Real Earnings Management and Future Performance. Global Business Review, 16(1), 21-34. http://dx.doi.org/10.1177/0972150914553505

Tebogo, B. (2011). Does the Enron Case Study Provide Valuable Lessons in the Early Detection of Corporate Fraud or Failure?. http://dx.doi.org/10.2139/ssrn.1906045

\section{Copyrights}

Copyright for this article is retained by the author(s), with first publication rights granted to the journal. This is an open-access article distributed under the terms and conditions of the Creative Commons Attribution license (https://creativecommons.org/licenses/by/4.0). 